\title{
Constraints to Pigeon Pea Production Under Semi-Arid Conditions in Puerto Rico'
}

\author{
Paul R. Hepperly and Rocio Rodriguez ${ }^{2}$ \\ ABSTAACT
}

Commercial pigeon pea lines and advanced lines from the UPA College of Agriculture Pigeon Pea Breeding Program were evaluated under rainfed conditions in Coamo, Puerto Rico, in 1981-82 and 1982-83. In the first growing season, yields were high (up to $8,420 \mathrm{~kg}$ of pods and seeds/ha) and comparable to high yields recorded at University Experiment Stations. In the second season, drought seriously curtailed yields (highest yield $4,860 \mathrm{~kg} / \mathrm{ha}$ ). Drought reduced yields by 25 to $75 \%$ depending on the pigeon pea variety. Early maturing lines escaped drought damage, and traditional varieties appeared more tolerant than advanced lines developed in the Agricultural Experiment Station. The yield stability of 'Kaki' seems to be highly associated with its extreme indeterminate yielding pattern. 'Kaki' may better utilize off-season rains in comparison to highly determinate varieties. Hand harvesting of pigeon peas was favored by upright branching and large terminal pod clusters. Larger seeded pigeon pea lines appeared lower in seed quality as evidenced by increased numbers of visibly damaged seed. Up to $20 \%$ of seeds of 147 were moldy or malformed. Besides periodic drought, waterlogging of pigeon pea solls appeared to be a major factor limiting yields. In areas of pigean pea fields which retain water, yield losses were 5 to $60 \%$.

\section{INTRODUCTION}

In Puerto Rico, over 6,000 ha are devoted to commercial production of pigeon peas. Pigeon peas are the most widely cultivated legume locally. Two canneries, one in Villalba, and the other in Orocovis, are devoted to pigeon pea processing. The pigeon pea harvest is valued at over $\$ 6$ million annually. Because local demand outstrips local production, sizable quantities of pigeon peas are imported yearly (3).

Pigeon peas, a crop of the semiarid tropical lowlands, are noted for their tolerance of low and erratic rainfall and low fertility levels (4). In Puerto Rico the semi-arid regions producing pigeon peas do not support other commercial crops without supplemental irrigation. These areas are generally economically depressed with high rates of unemployment. Pigeon peas are very important for the subsistence of the local population.

Because of nitrogen fixing bacteria, pigeon peas can help enrich the soil. Nitrogen left from pigeon peas can be used by subsequent crops grown in rotation (9). Pigeon peas play an important role in improving soil structure as well as fertility. The tap and fibrous roots of pigeon peas are important in penetrating compacted soil and subsoil layers and

\footnotetext{
${ }^{1}$ Manuscript submitted to Editorial Board November 29, 1984.

${ }^{2}$ Associate and Assistant Professors of Plant Pathology, Department of Crop Protection, College of Agricultural Sciences, Mayagüez Campus, University of Puerto Rico 00709.
} 
stimulating soil formation processes. Extensive development of pigeon pea roots is one factor related to its resistance to drought (13).

Weed control is another role for pigeon peas. Although pigeon peas do not tolerate weeds well in initial stages of growth, ${ }^{3}$ in late growth stages weeds are actively suppressed. Pigeon pea leaf mulches cause significant reduction in the development of grasses (7).

Nutritionally pigeon peas not only provide a cheap source of protein but a rich source of iron (10). Anti-nutritional and flatulence factors which have been found in many other grain legumes have not been detected in pigeon peas (4). Moreover, consumption of pigeon peas reduces blood stream lipids (cholesterol) which are related to cardiovascular diseases (12), which are the chief cause of poor health in adults in Puerto Rico and the United States today (1).

Over 45 pathogens, numerous species of insects, and weeds plague normal production of pigeon peas $(4,11)$. Pests limit pigeon pea production even though pigeon peas are considered more pest resistant than many other crops. Exercising better control of pests will likely lead to increased profitability of pigeon peas.

The purpose of this paper is to disseminate information from evaluations of promising pigeon pea lines developed by the University of Puerto Rico College of Agricultural Sciences Experiment Station when grown in the traditional pigeon pea zone of Puerto Rico and with the traditional methods of culture. Insights into local constraints of pigeon pea production and drawbacks of newly developed lines under local conditions can be used to understand why farmers have not accepted newly developed lines and how breeding programs can be directed to produce lines of greater acceptance by farmers.

\section{MATERIALS AND METHODS}

\section{SOIL AND CLIMATIC CONDITIONS}

The experiments were conducted in Carlos Cardona's farm in Barrio Santa Catalina in Coamo, Puerto Rico. In the two growing seasons different fields on the same farm, in the same soil type and with slopes of similar inclination, were used. In both cases, the experimental areas were rotated from a native grass pasture. The experimental soil was of the Callabo association with a slope of 20 to $40 \%$. This association is common in the semi-arid zone from Coamo to Villalba, the heart of commercial pigeon pea production in Puerto Rico. The Callabo soil is a fine mixed isohyperthermic of the subgroup Typic Ustrpepts of the order Inceptisols (6). These soils are of volcanic origin with a high natural fertility and permeability but with low available water capacity and a pH

${ }^{3}$ M. Diaz, personal communication. 
of approximately 6.8 to 7.3 . Annual rainfall ranges from 25 inches (approximately $630 \mathrm{~mm}$ ) to 50 inches (approximately $1270 \mathrm{~mm}$ ) with mean annual temperatures of 76 to $78^{\circ} \mathrm{F}$ (approximately 25 to $26^{\circ} \mathrm{C}$ ). Local rainfall for the months of June through December was 3.56, 2.25, $6.27,6.48,2.53,3.02$, and 1.93 inches for the 1981-82 growing season, and $2.10,2.26,2.20,2.53,2.03,0.87$, and 0.27 inches for the 1982-83 growing season.

$1981-82$

Eighteen pigeon pea lines were planted in Barrio Santa Catalina in Coamo, Puerto Rico, July 2, 1981. Fifteen entries were advanced lines of the University of Puerto Rico College of Agricultural Sciences Experimental Station pigeon pea breeding program and the rest were commercial cultivars used in Puerto Rico. A randomized complete block field design with four replications was used. Plots consisted of two $6 \mathrm{~m}$-long rows with an interrow spacing of $1 \mathrm{~m}$. Fifty seeds were evenly planted for each $6 \mathrm{~m}$-row. No fertilizer was applied before, during or after the cropping cycle. Emergence counts were taken 3 and 5 weeks after planting. Field observations were made on a bi-weekly basis until harvest. Plots were harvested when pods were in full green to yellow pod stages (December through February). Stand-yield associations were established by calculating the most significant polynomial equation for the overall experiment. These same associations were calculated for waterway and nonwaterway sections of the planting. Entry means were separated according to Fisher's Least Significant Difference (FLSD).

\section{$1982-1983$}

Eight pigeon pea lines were planted June 16, 1982. Four of the entries were advanced lines from the UPR pigeon pea breeding program which were selected for their superior yields in 1981-82. Four Puerto Rican commercial cultivars (2B-Bushy, Kaki, Blanco, and Pinto) were used as standards. A randomized complete-block field design with four replications was used. Plots consisted of four $3 \mathrm{~m}$-long rows spaced $1 \mathrm{~m}$. In each row, 25 seeds were evenly planted. No fertilizer was applied before, during, or after the cropping cycle. Throughout the growing season, biweekly notes on field development were taken. From December to February, pods in full green to yellow stages were harvested from center rows. Mature dry seeds were harvested from border rows in each plot to determine dry seed quality. Data on seed quality was taken on random 100-seed samples from each replication. Parameters included were: 1) 100-seed weight, 2) visual appearance, and 3) number of damaged seeds. During both growing seasons disease notes were taken. Significant rust 


\section{JOURNAL OF AGRICULTURE OF UNIVERSITY OF PUERTO RICO}

was noted during the $1982-83$ season and varietal susceptibility was rated. To determine the influence of drainage on yield, we statistically compared upslope and downslope replications with a paired $t$ test.

\section{RESULTS AND DISCUSSION}

1981-82-COAMO

The following tabulation shows fresh pod and seed yields ranged from 5,800 to $7,200 \mathrm{~kg} / \mathrm{ha}$ for standard commercial cultivars.

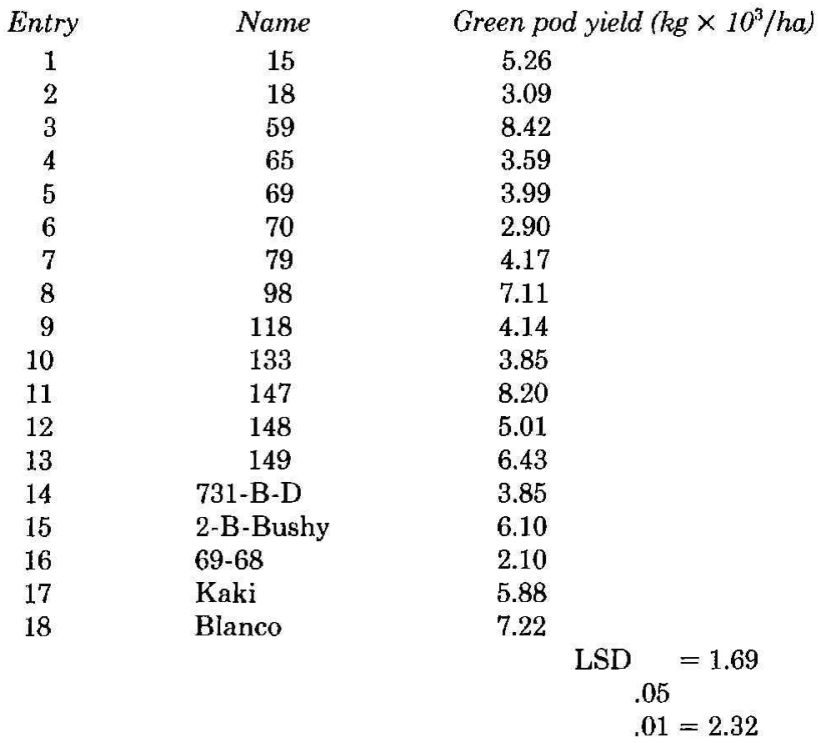

Lines $59(8,420 \mathrm{~kg} / \mathrm{ha})$ and $147(8,200 \mathrm{~kg} / \mathrm{ha})$ equaled or surpassed yields of the standard lines. Lines $98(7,100 \mathrm{~kg} / \mathrm{ha})$ and $149(6,400 \mathrm{~kg} / \mathrm{ha}) \mathrm{did}$ not differ significantly in yield from the standard lines. Lines 15 and 184 did not differ in yield from the poorest standard, but these and other advanced lines appeared inferior in yield and were not tested further. Yields recorded were comparable to high yields reported in Puerto Rico (5).

\section{2-83-COAMO}

No statistical differences were found among the yields of four advanced lines and four commercial varieties of pigeon peas as shown in the 
following tabulation. Yields ranged from 2,900 to $4,900 \mathrm{~kg} / \mathrm{ha}$. Yields were lower than 1981-82 apparently because of insufficient precipitation. Losses in pigeon pea production of $25 \%$ to $75 \%$ appeared to be related to drought stress.

$\begin{array}{ccc}\text { Entry } & \text { Name } & \text { Green pod yield }(\mathrm{kg} \times 10 / \mathrm{ha}) \\ 1 & 59 & 2.90 \\ 2 & 98 & 3.78 \\ 3 & 147 & 3.78 \\ 4 & 149 & 4.86 \\ 5 & \text { 2-B-Bushy } & 3.70 \\ 6 & \text { Blanco } & 4.14 \\ 7 & \text { Pinto } & 3.78 \\ 8 & \text { Kaki } & 4.42\end{array}$

TABLE 1.-Production trends for early and late maturity advanced generation experimental pigeon pea lines and traditional varieties under high and low yield environments during 1981-82 and 1982-83, respectively, in Coamo, Puerto Rico

\begin{tabular}{lcc}
\multicolumn{1}{c}{ Item } & \multicolumn{2}{c}{$\begin{array}{c}\text { Mean green pod yield } \\
\left(\mathbf{k g} \times 10^{3} / \mathrm{ha}\right.\end{array}$} \\
\cline { 2 - 3 } & $\begin{array}{c}\text { High yield } \\
81-82\end{array}$ & $\begin{array}{c}\text { Low yield } \\
82-83\end{array}$ \\
\hline $\begin{array}{l}\text { Two best experimental lines of early matu- } \\
\text { rity }\end{array}$ & 7.31 & 4.32 \\
$\begin{array}{l}\text { Two best experimental lines of late matu- } \\
\quad \text { rity }\end{array}$ & 7.77 & 3.34 \\
$\begin{array}{l}\text { Two best traditional varieties } \\
\text { Advantage of late lines over early lines }\end{array}$ & 6.55 & 4.28 \\
$\begin{array}{l}\text { Advantage of early over late lines } \\
\text { Advantage of new select lines over tradi- } \\
\quad \text { tional varieties }\end{array}$ & $6.3 \%$ & - \\
Advantages of traditional varieties over & - & $29.8 \%$ \\
$\quad$ new lines & $15.3 \%$ & - \\
\hline
\end{tabular}

1 Total rainfall during the production cycle (June through December) was 26.04 inches $(651 \mathrm{~mm})$ in $1981-82$ and 12.26 inches $(311 \mathrm{~mm})$ in $1982-83$.

\section{YEAR TO YEAR COMPARISON}

On the basis of yields, 1981-82 could be classified as a high yield season and $1982-83$ as a low yield season. Trends in yield between the years will be discussed. Under the high yield environment, new advanced lines were superior in yield to standard cultivars. Yields of late maturity lines exceeded those of early maturity lines (table 1). Under the high yield environment the best advanced lines were able to outyield standard cultivars by $15.3 \%$. In the same environment the yields of late maturity 
advanced lines exceeded those of early maturing ones by $6.3 \%$. Relative yielding capacity of pigeon pea lines changed in the low yield environment of 1982-83. Early maturity advanced lines had a $29.8 \%$ advantage in yield over the late maturity lines. Under the low yield environment, standard cultivars were superior to advanced lines by $11.8 \%$.

The highest yielding line in 1981-82 (line 59) was the lowest in 198283 (table 2). Kaki and 149 were not among the highest yielding lines in 1981-82, but showed yields higher than the other lines in the low yield environment of 1982-83. Under the low yield environment, 149 and Kaki outyielded 59 by more than $30 \%$.

Early maturity lines outproduced late lines under the low yield environment of 1982-83. Early maturity may help pigeon peas avoid severe seasonal drought which may affect reproductive stages of the pigeon peas. Pigeon peas usually depend on residual moisture from the rainy

'T'ABLE 2.-Pigeon pea yields 1981-83 and the apparent site specific stability of pigeon pea lines in two grouing seasons with diverse moisture regimes in Coamo, Puerto Rico'

\begin{tabular}{cccc}
\hline Cultivar & \multicolumn{2}{c}{ Green pod yield $(\mathrm{kg} \times 10 / \mathrm{ha})$} & $\begin{array}{c}\text { Yield stability } \\
82-83\end{array}$ \\
\cline { 2 - 3 } & $\mathbf{8 1 - 8 2}$ & $82-83$ & $81-82$ \\
\hline 59 & 8.42 & 2.90 & 0.34 \\
98 & 7.11 & 3.78 & 0.53 \\
147 & 8.20 & 3.78 & 0.46 \\
149 & 6.43 & 4.86 & 0.76 \\
2-B-Bushy & 6.10 & 3.70 & 0.61 \\
Blanco & 7.22 & 4.14 & 0.57 \\
Kaki & 5.88 & 4.42 & 0.75
\end{tabular}

${ }^{1}$ Total rainfall during the production cycle (June through December) was 26.04 in (661 $\mathrm{mm})$ in $81-82$ in $(311 \mathrm{~mm})$ in $82-83$.

season to complete their development. Early lines also may avoid buildup of pod-borers, which take a greater toll in the late season.

Despite its lateness, Kaki appeared to have stability in yield at our site compared to other lines tested. The extreme indeterminant yielding pattern of Kaki may allow it to utilize off-season precipitation during its reproductive stages. Superiority of indeterminant lines of soybeans in terms of yield stability was demonstrated in the North Central United States (2).

\section{HORTICULTURAL AND MORPHOLOGICAL TRAITS}

Compared to all other lines 2B-Bushy had the most compact period of harvest and the earliest maturity (table 3 ). Compact harvest period favors efficient mechanical harvesting. On the other hand, 2B-Bushy is not adapted for efficient hand harvest because of its small scattered pod 
clusters. Long terminal pod clusters favor efficient hand harvest of Blanco, Pinto and Kaki. Hand harvest is easiest in lines of medium height (1 to $2 \mathrm{~m}$ tall) and with upright branching. On the basis of drought avoidance and consumer demand for pigeon peas, early maturity lines should be stressed in breeding programs. Fresh pigeon pea prices are very high before Christmas and drop thereafter (11).

Rust was more severe in 1982-83 than in 1981-82. Line 98 was highly susceptible to rust. Although line 98 has excellent horticultural traits its extreme susceptibility to rust would make its release unwise. Kaki, Pinto, and Blanco which are standard farmer cultivars appear highly tolerant of pigeon pea rust (table 3 ).

TABLE 3.-Horticultural and morphological characteristics of pigeonpea lines evaluated in 1981-8.3 in Coamo, Puerto Rico

\begin{tabular}{|c|c|c|c|c|c|c|}
\hline \multirow[b]{2}{*}{ Lines } & \multicolumn{2}{|c|}{$\begin{array}{l}\text { Estinuated number of } \\
\text { economic harvests }\end{array}$} & \multirow{2}{*}{$\begin{array}{l}\text { Terminal }^{\mathrm{l}} \\
\text { pod } \\
\text { cluster }\end{array}$} & \multirow{2}{*}{$\begin{array}{c}\text { Branch } \\
\text { orientation }\end{array}$} & \multirow{2}{*}{$\begin{array}{l}\text { Comparative } \\
\text { maturity }\end{array}$} & \multirow{2}{*}{$\begin{array}{l}\text { Rust. } \\
\text { reaction }\end{array}$} \\
\hline & $\begin{array}{c}81-82 \\
(\mathbf{L}, 200 \mathrm{~kg} / \mathrm{ha})\end{array}$ & $\begin{array}{c}82-83 \\
(750 \mathrm{~kg} / \\
\text { ha) }\end{array}$ & & & & \\
\hline 59 & 5 & 3 & Small & Upright & Mod. Late & MS \\
\hline 98 & 3 & 2 & Small & Upright & Mod. late & VS \\
\hline 147 & 3 & 2 & Small & Lateral & Early & MR \\
\hline 149 & 4 & 3 & Small & Lateral & Early & $\mathrm{S}$ \\
\hline 2-B-Bushy & I & 2 & Small & Lateral & Very early & $\mathrm{S}$ \\
\hline Blanco & 2 & 1 & Large & Upright & Early & MR \\
\hline Pinto & - & 1 & Large & Upright & Medium & $\mathrm{MR}$ \\
\hline Kaki & 3 & 4 & Large & Upright & Very late & $\mathrm{MR}$ \\
\hline
\end{tabular}

${ }^{1}$ A sinall terminal pod cluster had from 5 to 15 pods, whereas a large terminal pod cluster had from 15 to 25 pods.

${ }^{2} \mathrm{VS}=$ very susceptible; $\mathrm{S}=$ susceptible; $\mathrm{MS}=$ moderately susceptible; and $\mathrm{MR}=$ moderately resistant.

\section{SEED QUALITY}

Pigeon pea lines differed in their seed size, seed damage, and their appearance (table 4). Seed size can affect the vigor of seeds, their susceptibility to invasion and decay, mechanical damage, and their acceptance by farmers and consumers. Large seeded lines are favored by farmers and consumers in Puerto Rico. Line 147 had the biggest green size but was low in 100-seed weight based on production of shrivelled mature seed (table 4). Seed damage increased along with seed size. Achieving high visual seed quality and good seed viability may mean compromising the desirability of large seed. Too much emphasis on large seed size may make it harder to breed for other important pigeon pea characters such as yield. 


\section{DRAINAGE}

Hepperly and Rodríguez (8) found poor pigeon pea performance associated with waterlogged soils in farmer surveys and in laboratory experiments. Chlorosis, retarded root and shoot growth, and low yields were typical symptoms in pigeon peas growing under water saturated soils. Stanton (14) noted similar symptoms in pigeon peas in a poorly drained soil in Africa. Hepperly and Rodriguez (8) noted no pigeon pea emergence at soil saturations of above $75 \%$. There is little quantitative data on the effects of drainage and soil saturations on pigeon peas in the field in Puerto Rico. The effects of drainage on pigeon pea yields were analyzed for two growing seasons (table 5 and figure 1). Emergence and yield

TABLE 4.-Seed quality characteristics of pigeonpea lines evaluated in 1982-83 in Coamo, Puerto Rico ${ }^{1}$

\begin{tabular}{|c|c|c|c|c|}
\hline Lines & Damaged seed (\%) & Quality score ${ }^{\mathrm{J}}$ & $\begin{array}{l}\text { 100-speed } \\
\text { weight (g) }\end{array}$ & $\begin{array}{l}\text { Green } \\
\text { seed } \\
\text { size }^{2}\end{array}$ \\
\hline 59 & 12.0 & 4.0 & 15.0 & 3.5 \\
\hline 98 & 9.0 & 4.5 & 18.9 & 4.0 \\
\hline 147 & 20.0 & 5.0 & 16.3 & 5.0 \\
\hline 149 & 4.0 & 2.0 & 14.2 & 3.0 \\
\hline 2-B-Bushy & 6.0 & 3.0 & 14.6 & 3.0 \\
\hline Blanco & 8.0 & 4.0 & 19.8 & 4.5 \\
\hline Pinto & 5.0 & 2.0 & 16.4 & 3.0 \\
\hline Kaki & 9.0 & 4.0 & 118.4 & 4.0 \\
\hline \multicolumn{2}{|c|}{ LSD } & \multicolumn{2}{|l|}{ LSD } & \\
\hline & $35 \quad 7.3$ & \multicolumn{2}{|c|}{.052 .0} & \\
\hline & 10.7 & \multicolumn{2}{|c|}{.012 .9} & \\
\hline
\end{tabular}

${ }^{1}$ Seed quality score-1. excellent; 2. good; 3. fair; 4. poor; 5 , very poor.

${ }^{2}$ Green seed size - 1. very small; 2 . small; 3 . medium; 4. large; 5 . very large.

relationships were calculated in waterway and nonwaterway sectors of field experiments in 1981-82 (fig. 1). In natural waterways both pigeon pea stand and yield were decreased. Furthermore, at equivalent populations, yields were inferior in waterway sectors. In 1982-83 we compared upslope and downslope replications for yield (table 5). Downslope replications had a greater tendency to accumulate water. Although this was a dry year, particularly during the reproductive stages several heavy rains fell during the early seedling and vegetative stages. A $21.9 \%$ loss in yield was found downslope (table 5). Our survey observations, laboratory work, and field experiments suggest periodic over-saturation of pigeon pea soils is a major yield constraint. Within affected areas yield losses range from 5 to $60 \%$. Cultural practices which improve drainage around the pigeon 
TABLE 5.-Yield losses associated with down slope replications of eight pigeonpea lines grown in Coamo, Puerto Rico during 1982 through 1983

\begin{tabular}{ccccc}
\hline \multirow{2}{*}{ Lines } & \multicolumn{3}{c}{ Yield $(\mathbf{k g} / \mathrm{ha})$} & \multirow{2}{*}{ Percentage loss } \\
\cline { 2 - 4 } & Upslope & Downslope & Difference & \\
\hline Kaki & $3,859.2$ & $3,513.6$ & 345.6 & 9.0 \\
2B-Bushy & $3,110.4$ & $2,937.6$ & 172.8 & 5.6 \\
149 & $3,916.8$ & $3,571.2$ & 345.6 & 8.8 \\
147 & $3,744.0$ & $3,340.8$ & 403.2 & 10.8 \\
Blanco & $3,456.01$ & $2,764.8$ & 691.2 & 20.0 \\
Pinto & $3,225.6$ & $2,419.2$ & 806.4 & 25.0 \\
59 & $3,456.0$ & $1,144.0$ & $2,016.0$ & 58.3 \\
98 & $3,916.8$ & $2,419.2$ & $1,497.6$ & 38.2 \\
$\overline{\mathbf{x}}$ & $3,585.6$ & $2,800.8$ & 784.8 & 21.9 \\
\hline
\end{tabular}

${ }^{1}$ 'The statistically significant difference $(\mathrm{P}=0.01)$ is based on a paired $t$-test.

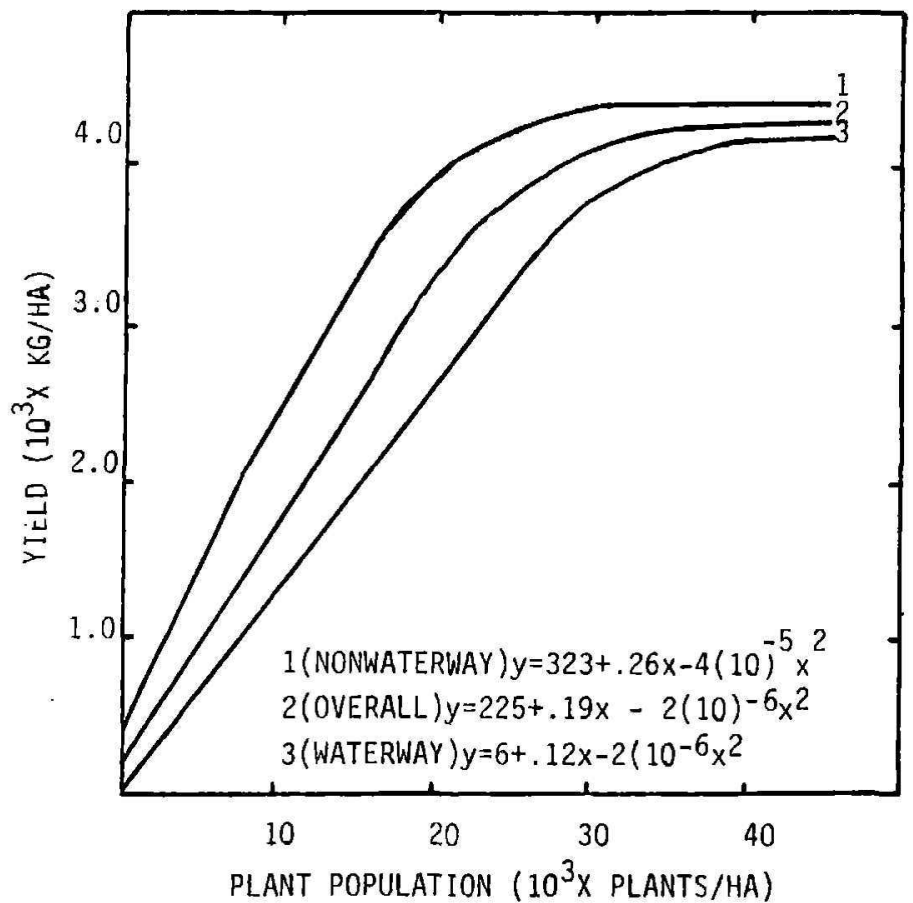

Fig. 1.--The relationship between pigeonpea plant population and pigeonpea pod and seed yield for 18 lines planted in waterway and nonwaterway sections of the Coamo experimental field in 1981-1982. 1 and 3 were based on data from 36 plots each, whereas 2 was based on the overall ( 72 plots). Lines were calculated using the most significant power function. 
pea plant will likely reduce pigeon pea losses, thus increasing yield. These may include planting on hills and ridges or possibly tilling low lying area with impeded drainage or those receiving heavy runoffs. Selection of pigeon peas with greater tolerance to waterlogging is another feasible strategy to reducing losses.

\section{RESUMEN}

En 1981-82 y 1982-83 se evaluaron en Coamo, Puerto Rico, algunas lineas avanzadas del programa del Colegio de Agricultura de la Universidad de Puerto Rico para el mejoramiento del gandul y algunas variedades comerciales. Los altos rendimientos obtenidos en la primera siembra fueron muy similares a los rendimientos informados por la Estación Experimental Agrícola. En la segunda siembra la sequía disminuyó los rendimientos entre 25 y $75 \%$ dependiendo de la variedad. Algunas líneas de maduración temprana escaparon de los daños causados por la sequia. Las variedades comerciales tradicionales la resistieron mucho mejor que las líneas nuevas. Aparenternente, la estabilidad en la producción de la cultivar Kaki está relacionada con su amplio periodo de reproducción que permite un mejor aprovechamiento de las lluvias fuera de época. La recolección a mano es más fácil dada la ramificación vertical y los ramilletes con muchas vainas terminales. Las líneas de semilla grande mostraron una tendencia hacia un mayor número de semillas con daños visibles. Además de la sequía, la sobresaturación del suelo representó otro factor limitativo para el rendimiento del gandul. En los ensayos las plantas localizadas en áreas expuestas a inundación mostraron reducciones en rendimiento de 5 a $60 \%$.

\section{LITERATURE CITED}

Anonymous, 1976. Man's Body, Bantam Books, Inc., New York, N.Y.

Beaver, J. S. and R. R. Johnson, 1981. Yield stability of determinant and indeterminant soybeans adapted to the northern United Stales. Crop Sci. 21: 449-53.

Commonwealth of Puerto Rico, 1981. Facts and Figures on Puerto Rico's Agriculture, 1978/ 79 to 1979/80. Dep. Agric. Office of Agricultural Statistics, Santurce, Puerto Rico.

Duke, J. A., 1981. Handbook P of Legumes of world Economic Importance, Plenum Press, New York.

Estación Experimental Agrícola, 1977. Conjunto Tecnológico para la Producción de Gandules, Univ. P.R., Rio Piedras.

Gierbolini, R. E., 1979. Soil Survey of Ponce Area of Sourthern Puerto Rico, USDA, Soil Conservation Service.

Hepperly, P. R. and M. Diaz, 1983. The allelopathic potential of pigeon peas in Puerto Rico, d. Agric. Univ. P.R., 67(4): 453-63.

- - and R. Rodriguez, 1984. Mycofloral succession and viability losses of pigeon peas in Puerto Rico. J. Agric. Univ. P.R., 68 (1): 19-31.

Lugo-López, M. A. and R. Abrams, 1981. High yields of non-fertilized protein-rich pigeon 
peas on tropical soils low in inherent fertility of Puerto Rico. J. Agric. Univ. P.R., 65 (1): $21-8$.

Morton, J. F., 1976. The pigeon pea a high-protein tropical bush legume. Hort. Sci. 11 (1): 11-9.

--, R. E. Smith, M. A. Lugo-López and R. Abrams, 1982. Pigeon peas: A valuable crop of the tropics. College of Agriculture Univ. P.R., Mayagúez, P.R.

Prema, L. and P. A. Kurup, 1973. Hypolipidaemic activity of the protein isolated from Cajanus cajan in high fat-cholesterol diet fed rats, Ind. J. Biochem. Biophys. 10 (4): 293-96.

Rivera, E., S. Silva and J. Vicente-Chandler, 1983. Distribution of pigeon pea, cassava, coffee, and grass roots in an Ultisol, J. Agric. Univ. P.R., 67 (3):278-85. 